\title{
Gender in Farmer Household Livelihood Strategies in South Sulawesi
}

\author{
Firdaus W. Suhaeb* \\ Departemen of Sociology \\ Faculty of Social Science \\ Universitas Negeri Makassar \\ Makassar, Indonesia \\ firdaus.w.suhaeb@unm.ac.id
}

\author{
Ernawati Syahruddin Kaseng \\ Departement of Agricultural \\ Technology Education \\ Faculty of Engineering \\ Universitas Negeri Makassar \\ Makassar, Indonesia \\ ernawatisyahruddin71@unm.ac.id \\ Abdul Rahman \\ Fakultas Ilmu Sosial \\ Universitas Negeri Makassar \\ Makassar, Indonesia \\ abdul.rahman8304@unm.ac.id
}

\author{
Sampean \\ Departement of Rural Sociology \\ Graduate School \\ Institut Pertanian Bogor \\ Bogor, Indonesia \\ sampean_pian@apps.ipb.ac.id
}

\begin{abstract}
The change in the economic transition from subsistence to the formal economic system has brought about changes in the pattern of living in society, especially in farmer households. The research objective was to analyze and provide an overview of the livelihood strategies of farmer households in South Sulawesi which are gender nuanced. As well, the division of labor and time allocation based on the roles between women and men who work in each realm both formal and informal in on-farm, off-farm, and non-farm. This research uses a qualitative approach. Qualitative data were obtained through observation, interviews, literature study and secondary data in the form of previous research and disaggregated data from the Central Bureau of Statistics. Analysis of research data using qualitative analysis, where the data is processed by classification and analyzed in a qualitative narrative. The results showed that changes in the household income system of the Bugis-Makassar ethnic farmers, where women tend to prefer off-farm than on-farm. Meanwhile, involvement in agriculture is still dominated by men. Household livelihood strategies, namely men and women must play a role without limiting access, control, participation and benefits from one another. Changes in roles and time allocations were driven by an economic transition that gave rise to various alternative jobs, both off-farm and non-farm along with the increase in employment space in the formal and informal sectors.
\end{abstract}

Keywords: Gender, Livelihood strategy, Economic transition, Household

\section{INTRODUCTION}

The change in the economic transition from subsistence to the formal economic system has brought about changes in the pattern of living in the community, especially in rural farmer households. This change encourages heterogeneity (diversity) of income patterns of farmers in rural areas which lead to an economic transition. The economic transition phase in rural areas is due to the opening of access of rural communities to the formal and informal economic sectors in meeting household needs. The formal sector refers to the linkage of structural work mechanisms and activities between the government and society based on legality, including official ties, civil servants and office employees. Formal economic sector activities as a source of livelihood, not from agricultural products, are used to meet household needs. Meanwhile, informal refers to activities that are not legitimate and illegal from the state structure[1] [2][3]. In the definition of BPS (2015) the duality of formal and informal economy is based on work status where formal work is identified as a business that has or is assisted by employees or laborers. Apart from this sector is the informal sector. From the definition, BPS implies that farmers are informal workers.

The income pattern that was formed due to the emergence of formal sectors in rural areas, including rural areas in South Sulawesi, made it possible to absorb labor to fulfill household needs. Mingione also states that the formation of the formal sector in society will encourage the emergence of the informal sector[1]. The formation of the informal sector provides space and access for women to resources and fulfillment of their household. The formation of the formal and informal economy according to Salman is a space for disharmony between various systems to take place. This disharmony begins to shift the pattern values that are formed in society. Although, in some regions and countries there is a tendency that the informal sector has a female face [4].

Another trend of feminization in the informal sector can be seen in Trupp and Sananta in the ethnic minority ethnic group of Thailand's Urban Akha who sell souvenirs around in tourist areas and urban communities. The emergence of various forms of feminization in various sectors cannot be separated from the strategy of division of labor and allocation of time that occurs in farmer households [5]. The actual involvement of women in the public sphere is a step to improve the quality of life in a household. On the other hand, the tendency of women to be involved in the public sphere, agricultural and non-agricultural production (onfarm) is independent of the pressure and economic demands of the family to meet the needs of life and to improve social status in rural communities. This condition can also be seen in farmer households in rural South Sulawesi.

Meanwhile, what about the strategy for the distribution of household subsistence needs of farmers in South Sulawesi who are Bugis - Makassar ethnicity which tends to 
dominate men over women. Idris's research shows that ethnic Bugis - Makassar women are in a marginalized position and are under the power of men and families, especially Bugis - Makassar women. This position shows that women are in an iron cage of male power and places women as passive creatures. This view is quite problematic when faced with the conditions of ethnic Bugis Makassarese women in South Sulawesi who have penetrated many informal and off-farm sector jobs including trade and agricultural production in the public sphere [6].

Based on the research problems above, the purpose of this study is to analyze and provide an overview of the household livelihood strategies of the Bugis-Makassar ethnic farmers in South Sulawesi with a gender economy nuance. This is because the strategies they apply in the lives of farmers in South Sulawesi who are Bugis - Makassar are quite diverse in meeting the needs of their households by penetrating the formal and informal rural sectors based on the division of labor and the allocation of time between men and women. The division of labor and allocation of time is identified based on the division of roles between women and men who work in each realm both formal and informal in on- farm, off-farm and non-farm.

\section{METHODOLOGY}

Considering the context and characteristics of the ethnic diversity of Indonesian society. Each ethnic group has a different livelihood strategy. Ethnicity is very much influenced by the ecological scope and situation that develops in the community [7].

This research only focuses on the household livelihood strategies of farmers in the economic transition with gender nuances in rural areas of South Sulawesi, which of course will be different from other ethnic groups in Indonesia. For this reason, this study uses a qualitative approach. Qualitative data were obtained from observations, in-depth interviews, literature studies and secondary data in the form of previous research and disaggregated data from the Central Bureau of Statistics South Sulawesi. Research informants were determined on purpose. Then data validation techniques, namely through persistence of observations, and triangulation of sources. Analysis of research data using qualitative analysis, where the data obtained is then processed by classification and analyzed in a qualitative narrative. The stages of data analysis in this study used the Miles and Huberman model through the following stages: 1) Data reduction stage, 2) Data presentation stage, and 3) Conclusion / verification stage [8].

\section{RESULT AND DISCUSSION}

\section{A. Gender Nuances in Livelihood Strategies}

The gender livelihood strategy can be observed from the results of the Gender Development Index (IPG) of South Sulawesi for the last eight years showing a fluctuating trend. IPG shows the progress of development and empowerment for men and women. Therefore, this index is able to explain the gender gap among farmers in South Sulawesi who are Bugis - Makassar. IPG can be seen in the following Figure.1.:

Figure 1. Development of the 2010 Gender Development Index 2010-2018

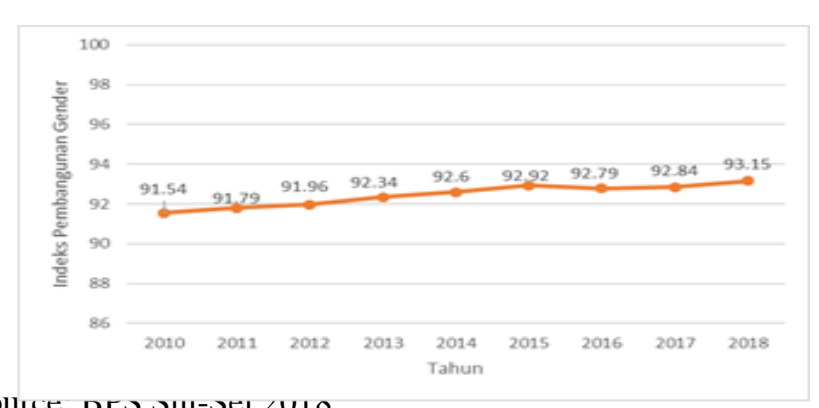

Source. DIS sul-sel $\angle U 10$

This gap is related to the ability to do to face changes in social situations with the emergence of various professions and sources of livelihood. The livelihood strategy is a response to changes in the social situation from an economic system to an economic duality system (formal and informal) as an economic transition. While these changes certainly change the principles of farmer life, which initially adopted a single income pattern that only depends on one source of agricultural income (on-farm) to become a double income (ie off-farm and non-farm).

In an economic transition, rural communities no longer focus on subsistence economic systems which only concern meeting household needs. However, it has shifted as a commodification of farming activities as a business or a source of income. Therefore, the livelihood strategy concerns the ability to support themselves both as a group and individually, work activities that support themselves, ownership of assets as ownership of wealth, and access and control over resources. This strategy deals with formal and informal economic activities that have gender nuances. The formal economy is closely related to non-farm economic activities which involve non-agricultural income, while the informal economy focuses on off-farm income which refers to activities that are not legitimate and illegal from the state structure.

The income pattern is very gendered with regard to the division of labor and the allocation of time. Based on BPS South Sulawesi in August 2015, the number of household managers was 781,250 thousand people while working $2,110,862$ million people in rural South Sulawesi. And, the number of people who work in the agricultural sector is $1,449,458$ million people. In other sectors, around 661,404 thousand people work both non-farm and off-farm. Of course, the data on household managers is dominated by women, who do not belong to the workforce. Meanwhile, those who work in the agricultural sector seem to involve women and men as well as other sectors, both formal and non-formal, which involve off-farm and non-farm economic activities.

The formation of livelihood patterns in the transition offarming communities depends on the challenges and the variety of social conditions faced by households or farming communities. In this condition, Dharmawan states that the livelihood system does not only involve making a living (means of living) but also involves a livelihood strategy [4]. Ellis also defines livelihood strategies as a result of the interaction between income, agricultural productivity, gender relations and property rights necessary to maintain living standards. Livelihood strategy is an entity of how to 
survive and develop the quality of household life [9]. Livelihood strategies will measure the strength of farmers to survive the conditions at hand. The livelihood strategy also concerns self-formulation to adapt to the environment at hand.

\section{B. Division of Work and Allocation of Work Time}

BPS disaggregated data for 2015 shows the involvement of women in agriculture. Gender-based classification of agricultural, livestock, fishery, forestry commodities can be seen in the following Figure:

Figure 2. Comparison of the activities of BugisMakassar ethnic livelihoods in rural South Sulawesi

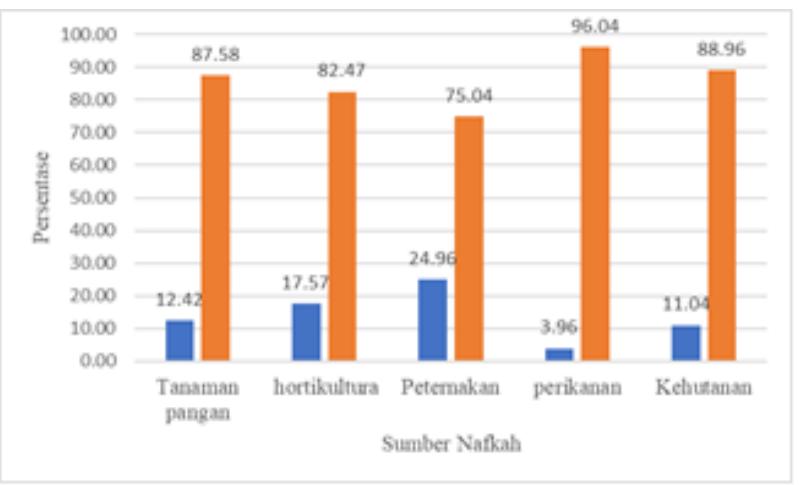

Source : BPS Sulsel 2015

This data shows that the highest involvement of women in livestock livelihood sources is $24.96 \%$ and the smallest involvement of women is in fisheries livelihood sources. Involvement of women in livestock livelihoods in raising, feeding and collecting livestock. These activities are not used as a source of income. Income is calculated based on family income.

The dominance of men's involvement in fisheries as a source of income is inversely proportional to the contribution of household income. The income contribution of women is greater than that of men. This result is shown from the report of the South Sulawesi Provincial Government in 2012 showing the contribution of women to the economic income of coastal households (especially in the marine fisheries sector), where the contribution of the wife's income is greater than that of the husband. The involvement of women in making a living in fisheries covers a whole series of activities, namely production, processing and marketing.

Rural communities in South Sulawesi have a dual income pattern involving other sector aspects, such as nonfam and off-farm. The involvement of women in the agricultural sector is still quite low, while the involvement of women as house keeping in 2016 amounted to $37.01 \%$ of the population who work in rural areas. Meanwhile, both women and men working in other sectors [non-farm and offfarm] amounted to $45.63 \%$.

The population who work in other sectors is quite large, at $45.63 \%$ who involve various occupations such as offfarm, for example transporting garden products, agricultural product traders, agricultural laborers, rice cutters (pa'dare: Bugis and Pasangki: Makassar). The off-farm sector is dominated by the informal sector. Meanwhile, the non-farm sector concerns formal and informal. Non-farm from the informal sector comes from building construction services, traders, drivers, and TKI while those from the formal sector come from office employees, civil servants, the military, and village officials. The high off-farm and non-farm rates indicate a transformation of social change in the rural areas towards the economic transition of industrial and urban communities. The impact of these changes shows that in the farming community in Selayan Sulawesi, who are of Bugis Makassar ethnicity, they are starting to leave the old tradition or subsistence income system with the formation of new income systems from off-farm and non-farm.

The tendency of feminization in the informal sector in rural South Sulawesi can also be seen in several regions and countries that tend to have a female face. This can be seen from the results of Trupp and Sananta's research, looking at the feminization process of souvenir sales based on factors of production and distribution of souvenirs to the ethnic minority ethnic migrant group of Urban Akha Thailand. The results of this study indicate that around $90 \%$ of souvenir sellers and producers are women [5]. the involvement of women in souvenir sales plays an important role in meeting the household needs of the Urban Akha ethnic minority in Thailand. Meanwhile, rural areas in China are inversely proportional to the situation in India and Thailand, Chinese women prefer to work in the off-farm sector to meet their household needs [10]. The shift of Chinese women's work from the agricultural or informal and off-farm sectors is due to the influence of the allocation of work time and higher income security in the off-farm sector. In addition, there are many alternative jobs outside agriculture that can increase household income for farmers in China.

This condition is in line with the Gender Development Index (GDI) of South Sulawesi, which is at the medium level of $67.20 \%$ [11]. The GDI can be seen that the Bugis Makassar ethnic group has experienced a shift. This shift can be seen from the involvement of women in the public sphere regarding livelihood strategies. Likewise, it can also be seen in the daily lives of women in rural South Sulawesi who have the habit of being diaspora actors who are encouraged by the search for halal sustenance (Dalle Madeceng) and are related to increasing family status [12].

Although the BPS data above also shows, that in Bugis Makassar farmer households in South Sulawesi, there is no feminization of agriculture with low involvement of women in the agricultural sector. This is due to the fact that rural women of the Bugis - Makassar ethnic group work more as house keepers. The high number of women as household guards is inseparable from the cultural and ecological influence of the Bugis - Makassar ethnic community, which views women as guardians of the siri. Therefore, the large number of men involved in the agricultural sector and other sectors is due to the Bugis - Makassar ethnic tradition of holding the male principle as the head of the household.

Meanwhile, the division of labor and the allocation of time between men and women in farmer households in South Sulawesi are carried out through the division of roles and responsibilities. The division of roles and responsibilities is a livelihood strategy implemented by farmer households. The division of roles can be seen from the research of Mulyoutami showing the role of women $(29.14 \%)$ in the mixed garden system, which has a higher proportion of the role of men $(26.78 \%)$. Meanwhile, in meeting the food needs of farming families, a higher 
proportion of the role of women is seen in irrigated rice fields [11].

The division of roles in the livelihood strategy with gender nuances in farmer households in South Sulawesi, namely that they still pay attention to traditional aspects that develop in society even though they are slowly being eroded due to the pressure of developing socio-economic changes, as well as the drive for development to change the locus of society. Although, in the Bugis - Makassar ethnic community, they tend to be ambiguous because women are given space for activities in the public arena and even have the opportunity to become leaders. In the Bugis - Makassar literature, the myth to Manurung is associated as a king and the bearer of enlightenment in the people of South Sulawesi. In another aspect of the tradition, the involvement of women as leaders is seen from the leadership process of Andi Tenri Olle who saved the collapse of his family's kingdom. In several traditions and communities in the Bugis - Makassar ethnic group, women are given leadership. In some places women become the backbone of the family by sharing roles with their husbands, men at home and women to the market. Therefore, the strategy of household livelihoods for the Bugis - Makassar ethnic peasants is in terms of exchange of labor and time allocation in which men and women must play a role without limiting access, control, participation, and benefits from one another.

In general, the concept of a livelihood strategy must absorb the implementation of gender mainstreaming, namely equal access to resources, equal participation in the development process including decision making, the same benefits in development, and the same control over resources in development. Hubeis states that gender mainstreaming will be meaningful if women are actively involved in development by linking their abilities and contributions with macro issues and the national agenda. In this context, the contribution of women is needed in the micro realm in maintaining household resilience[13]

Gender mainstreaming and livelihood strategies in economic transition have a close relationship due to the heterogeneity of the economic sector to improve the standard of living of a community or individual. Therefore, we can see the nuances of gender based on ethnicity in rural areas, from the extent to which they share roles and responsibilities in maintaining and building their households. In the rural context in China, women mostly work on off-farm income patterns to support the sustainability of their households [10]. The trend in China in economic transition in research by $\mathrm{Su}$ et al shows a decline in employment in the agricultural sector (on-farm) accompanied by an increase in workers in off-farm shutter[10]. Research conducted by Schutter in India and several countries in the African region shows an increasing trend of women in the agricultural sector [14].

\section{CONCLUSION}

Changes in the livelihood system that took place in Bugis - Makassar ethnic farmer households in South Sulawesi have a different tendency from rural China conditions where women prefer off-farm to on-farm. Meanwhile, the involvement of women in India in agriculture is dominated by women. The Bugis - Makassar ethnic group is still dominated by men. The livelihood strategy of farmer households in South Sulawesi, namely the exchange of labor domains and the distribution of time allocations in which men and women must play a role without limiting access, control, participation and benefits to one another. Changes in roles and time allocations were encouraged due to the economic transition which gave rise to various alternative jobs, both off-farm and non-farm.

These changes are influenced by the rate of industrial growth and urbanization with the increase in job spaces in the formal and informal sectors [15]. This attractiveness, lured the villagers around $45.63 \%$ to wrestle in this sector. In this context, depth of data is needed to explore the livelihood strategies of the Bugis - Makassar ethnic group, which are very gendered, which is not just statistical data. However, historical data from various literatures, observational results, and participatory data.

\section{ACKNOWLEDGMENT}

The researcher would like to thank the FIS-UNM leadership for funding this research. The greatest appreciation also goes to previous researchers in laying the foundations for analysis of research topics and preliminary data through the Central Sulawesi-Selatan Statistics Agency

\section{REFERENCES}

[1] E. Mingione, Fragmented societies: a sociology of economic life beyond the market paradigm. Blackwell, 1991.

[2] M. Alter Chen, Rethinking the informal economy: Linkages with the formal economy and the formal regulatory environment, no. 2005/10. WIDER Research Paper, 2005

[3] J. Davis and D. Pearce, "The non-agricultural rural sector in Central and Eastern Europe," World Bank Tech. Pap., pp. 111130, 2001.

[4] A. H. Dharmawan, "Sistem penghidupan dan nafkah pedesaan: Pandangan sosiologi nafkah (livelihood sociology) mazhab barat dan mazhab Bogor," Sodality J. Sosiol. Pedesaan, vol. 1, no. 2, 2007

[5] A. Trupp and S. Sunanta, "Gendered practices in urban ethnic tourism in Thailand," Ann. Tour. Res., vol. 64, pp. 76-86, 2017.

[6] N. I. Idrus, "Siri', gender, and sexuality among the Bugis in South Sulawesi," Antropol. Indones., 2014.

[7] R. D. Parke and R. Buriel, "Socialization in the family: Ethnic and ecological perspectives," Handb. child Psychol., vol. 3, 2007. M. B. Miles and A. M. Huberman, Qualitative data analysis: An expanded sourcebook. sage, 1994

[9] F. Ellis, Rural livelihood diversity in developing countries: evidence and policy implications, vol. 40, no. 1. Overseas Development Institute London, 1999.

[10] W. Su, T. Eriksson, L. Zhang, and Y. Bai, "Off-farm employment and time allocation in on-farm work in rural China from gender perspective," China Econ. Rev., vol. 41, pp. 34-45, 2016.

[11] H. L. Tata et al., "Will funding to Reduce Emissions from Deforestation and (forest) Degradation (REDD+) stop conversion of peat swamps to oil palm in orangutan habitat in Tripa in Aceh, Indonesia?," Mitig. Adapt. Strateg. Glob. Chang., vol. 19, no. 6, pp. 693-713, 2014.

[12] G. Acciaioli, "From economic actor to moral agent: Knowledge, fate and hierarchy among the Bugis of Sulawesi," Indonesia, no. 78, pp. 147-179, 2004.

[13] A. V. S. Hubeis, Pemberdayaan perempuan dari masa ke masa. IPB press, 2010.

[14] O. De Schutter, "The agrarian transition and the 'feminization' of agriculture," New Haven, 2013.

[15] F. W. Suhaeb and M. R. Ridha, "Trust on Fishpond Farmers Community in Pancana Village of Barru Regency," in 1st International Conference on Social Sciences (ICSS 2018), 2018. 